\title{
Asit-Baz Konusuna Yönelik Öz-Yeterlik Algı Ölçeğinin Geliştirilmesi ve Fen Bilgisi Öğretmen Adaylarının Asit-Baz Öz-yeterlik Algılarının İncelenmesi*
}

\section{The Development of Acid-Base Self-Efficacy Perception Scale and the Investigation of Pre-Service Science Teachers' Self-Efficacy Perceptions on Acid-Base}

\author{
Nail iLHAN ${ }^{* *}$ \\ Özge çiçEK ${ }^{* \star \star}$
}

Öz. Öğretmenlerin sınıftaki fen konularıyla ilişkili öz-yeterlik algılarının belirlenmesi önemlidir. Belirli kimya konularıyla ilişkili öğretmenlerin öz yeterlik algısını ortaya çıkaran çalışmaların yapılması gerekir. Bu çalışmanın amacı "Asit-Baz Konusuna Yönelik Öz-Yeterlik Algı Ölçeği" nin (ABÖAÖ) geliştirilmesi ve fen bilgisi öğretmen adaylarının asit-baz konusuna yönelik öz-yeterlik algılarının çeşitli değişkenler (Cinsiyet, sınıf düzeyi, mezun olunan lise türü, Genel kimya-II ders başarısı) açısından incelenmesidir. Tarama yönteminin kullanıldığı bu çalışmanın örneklemini dokuz farklı üniversiteden 982 fen bilimleri öğretmen adayı oluşturmaktadır. Bu çalışmada geliştirilen, beşli likert tipi olan ve 14 maddeden oluşan iki faktörlü ABÖAÖ veri toplama aracı olarak kullanıldı. ABÖAÖ’nün boyutlarının belirlenmesinde açımlayıcı ve doğrulayıcı faktör analizleri uygulanmıştır. Cronbach's Alpha güvenirlik katsayısı 0.823 olarak belirlenmiştir. Araştırma sonuçları fen bilimleri öğretmen adaylarının asit-baz konusundaki öz-yeterlik algı düzeylerinin cinsiyet, sınıf düzeyi ve "Genel Kimya-II" dersi başarı düzeyine göre değiştiğini göstermektedir. Fakat öğretmen adaylarının öz yeterlik algılarının mezun olunan lise türü açısından değişmediği ortaya çıkmıştır. Öğretmen adaylarının kimya ile ilgili öz-yeterlik algılarını geliştirmek için kimya konularına yönelik öz yeterliği araştıran çalışmalar yapılması alana katkı sağlayacaktır.

Anahtar Kelimeler: Öz-Yeterlik Algısı, Asit-Baz, Ölçek Geliştirme, Fen Bilgisi Öğretmen Adayı.

Abstract. It's believed that determining the teachers' perception of self-efficacy regarding related to science/chemistry subjects in classes is important. Studies about teachers' perceived self-efficacy related to a particular chemistry topic need to carry out.. The aim of this study is to develop "Acid-Base Self-Efficacy Perception Scale (ABSPS)" and to investigate the level of pre-service science teachers' self-efficacy perceptions on acid-base topic in terms of various variables (gender, grade, the type of high schools graduated and achievement at General Chemistry II lesson). Survey method was used. The sample of the study consists of 982 pre-service science teachers at eight different state universities. ABSPS, a five-point likert type, consists of two dimensions, developed in the study was used as the data collection tool. The dimensions of ABSPS were determined by exploratory factor analysis and confirmatory factor analysis. Reliability coefficient Cronbach's Alpha of ABSPS was 0.823 . The results show that pre-service science teachers' self-efficacy perceptions on acid-base topic vary in terms of gender, grade and "General Chemistry II" course scores. But, another results show that there were no significant differences preservice teachers' self-efficacy perceptions in terms of graduated high school type. Studies which are examining self-efficacy related to Chemistry topics would contribute to the literature in order to develop pre-service teachers' self-efficacy perception related to chemistry topics.

Keywords: Self-Efficacy Perception, Acid-Base, Scale Development, Pre-service Science Teacher.
Toplumsal Mesaj. Öz-yeterlik, bireyin bir işi yapıp yapamayacağına yönelik kişisel inancıdır. Bu araştırmada, fen bilimleri öğretmen adaylarının asit-baz konusuna yönelik özyeterlik algıları incelenmiştir. Araştırma sonuçları, öğretmen adaylarının asit-baz öz-yeterlik algılarının, mezun oldukları lise türüne göre değişmediğini; cinsiyetlerine, sınıf düzeylerine, asit-baz konusunun işlendiği ders olan "Genel Kimya-II" dersi başarılarına göre ise değiştiğini göstermektedir.

Public Interest Statement. Self-efficacy is a personal belief that someone can or cannot perform a task. In this article, it was investigated the selfefficacy perceptions of the preservice science teachers on acid-base topic. The results showed that acid-base selfefficacy perceptions did not change according to graduated high school. But it changed according to gender, university grade levels, and the "General Chemistry-II" course success.

\footnotetext{
* Bu çalışma Kilis 7 Aralık Üniversitesi Bilimsel Araştırma Proje Birimi tarafından desteklenmiş (Proje No: 2014/02/LTP02) olup Yrd. Doç. Dr. Nail iLHAN'ın danışmanlığında yürütülen Arş. Gör. Özge ÇiçEK'in Yüksek Lisans tez çalışmasından türetilmiştir.

${ }^{* *}$ Yrd. Doç. Dr., Kilis 7 Aralık Üniversitesi, Muallim Rıfat Eğitim Fakültesi, Fen Bilgisi Eğitimi, naililhan@gmail.com

${ }^{* * *}$ Arş. Gör., Kilis 7 Aralık Üniversitesi, Muallim Rıfat Eğitim Fakültesi, Fen Bilgisi Eğitimi, ozgecicek@kilis.edu.tr
} 


\section{GiRiş}

Eğitim sisteminin en önemli ögesi olan öğretmenlerin, eğitim sürecinde ve uygulamalarda karşılaştıkları durumlar ve bu durumlara karşı tepkileri, onların duyuşsal birtakım özelliklere (ilgi, tutum, motivasyon vb.) sahip olma düzeyleri ile ilişkilidir. Bu özelliklerden birisi de öğretmenlerin öz-yeterlik algılarıdır. Öz yeterlik algısı, bireyin bir işi yapabilme becerisi değil, o işi yaparken gerekli olan basamakları gerçekleştirmesi aşamasında, o işi başarıyla tamamlayıp tamamlayamayacağına ilişkin bireysel yargıları ve inançları olarak açıklanmaktadır (Bandura, 1977; Bong, 1995). Bireylerin çeşitli durumlarda başarılı olmalarında, kendilerinin yapabilme güçlerine olan inançları rol oynamaktadır (Satıcı, 2013). Sosyal öğrenme kuramında öz-yeterlik algısının önemini vurgulayan Bandura (1997)'ya göre, öz-yeterlik algısı kişilere, toplumlara ve alanlara göre değişebilir ve bireyin çevresi ile olan iletişimini etkileyebilir. Öz-yeterlik algısı yüksek olan bireylerin karşılaştıkları durumlarla başa çıkabilmedeki inançları yüksek seviyedeyken; öz-yeterlik algısı düşük olan bireylerin, kişisel yeteneklerine olan inançları düşük olduğundan bu bireyler bir görevi başarma arzularından çabuk vazgeçmektedirler (Bandura, 1997; Shultz \& Shultz, 2007; Wuebbles, 2006). Özyeterlik algısı, bireylerin düşünme biçimlerini, karşılaştıkları durumlarda nasıl davranacaklarını ve gayret sarf etme düzeylerini etkilediğinden bu algının olumlu ya da olumsuz olması bir performansı geçekleştirmeye yönelik olarak ya bireyleri güdüler ya da kendi kendilerine engel olmalarına neden olur (Bandura, 1989; Lee, 2003).

Bandura (1997) bireylerin öz-yeterlik algılarının oluşumunu etkileyen önemli faktörleri, "doğrudan deneyimler", "dolaylı deneyimler", "sözel ikna" ve "duygusal durum" olarak ifade etmiştir. Doğrudan deneyimler, bireyin gerçekleştirdiği davranışlarının sonuçlarını değerlendirmesini ve bu değerlendirme sonucunun başarılı ya da başarısız olmasını buna benzeyen diğer işleri için de yorumlamasını içerir (Bandura, 1997; Kemp, 2011). Dolaylı deneyimler bireylerin çevresindeki kişilerin deneyimlerini gözlemleyerek, o işin üstesinden gelip gelemeyeceklerine dair geliştirdikleri inançları ifade eder (Aydın, 2008; Özenoğlu Kiremit, 2006). Bireylerin çevresindeki kişilerin sözel yorumlarına bağlı olarak olumlu yorumların bireylerin cesaretlenmesini sağladığına; olumsuz yorumların ise geri çekilmelerine neden olduğunu açıklayan faktör sözel ikna olarak tanımlanmaktadır (Bandura, 1997; Kayhan Yardımcı, 2007). Bireylerin bir durumla başa çıkarken içinde bulundukları psikolojik hallerini ve bu hallerini kendilerinin nasıl algıladıklarını ifade eden duygusal durum da, öz-yeterlik algısı üzerinde etkili olan faktörlerdendir (Bandura, 1997).

Öz-yeterlik algısı ile ilişkili çalışmalara bakıldığında, odaklanılan alanlardan birisinin de öğretmenlerin öz-yeterlik algılarının incelenmesi olduğu görülmüştür (Gürlen, 2011; Özenoğlu Kiremit, \& Gökler, 2010; Sağır \& Bertiz, 2016). Bu çalışmalarda, öğretmenlerin öz-yeterlik algılarının yüksek olmasına bağlı olarak öğrenme-öğretme sürecindeki etkinliklerinin ve bu etkinliklerin öğrencilerin gelişimi üzerinde olumlu yönde etkileri olduğu sonucuna ulaşılmıştır (TschannenMoran, Woolfolk-Hoy \& Hoy, 1998). Yüksek öz-yeterlik algısına sahip olan öğretmenlerin mesleklerinde başarılı ve özenli olmalarının yanı sıra öğrenme-öğretmen sürecinde daha sabırlı olmaları öğrenci performanslarını da olumlu yönde etkiler (Aydın, 2008).

\subsection{Araştırmanın Gerekçesi}

Alan yazında öğretmenler üzerinde öz yeterlikle ilgili yapılan çalışmaların çoğunlukla; fen bilgisi öğretmen adaylarının öz-yeterlik inançları (Deniş ve Genç, 2010), akademik öz-yeterlik algıları (Gürbüzoğlu Yalmancı ve Aydın, 2014), fen öğretimine yönelik öz-yeterlik inançları (Karamustafaoğlu, Uluçınar Sağır ve Özkan, 2012), alternatif ölçme değerlendirme yaklaşımlarına yönelik öz-yeterlik düzeyleri (Buldur, 2009) ile ilgili olduğu görülmüştür. Bunlara ek olarak da öğretmen adaylarının biyoloji öğretimine yönelik öz yeterlik algılarının (Ekici, 2005; Köseoğlu, 2010), kimya dersine ilişkin öz yeterlik algılarının (Sezgin Saf, 2011), ilköğretim öğrencilerinin fen ve teknoloji dersine yönelik öz-yeterliklerinin incelendiği çalışmalara da (Hızlıok, 2012) rastlanmıştır.

Öğretmenler ve öğretmen adaylarının fen veya kimya alanında öz yeterlik algısına yönelik yapılan çalışmalarda kimya gibi belirli bir alanda kavramları bilme, açıklama, günlük yaşamla iliş̧kilendirebilme, sorgulama ve sorgulamalarına cevap bulabilmeye yönelik inançları ortaya koyan 
çalışmalara rastlanılmamaktadır. Bu çalışmada fen bilimleri öğretmen adaylarının asit-baz konusuna yönelik öz-yeterlik algılarının ortaya konulması düşünülmüştür. Bununla birlikte alan yazında asit-baz konusuna yönelik öz-yeterlik algılarını belirleyecek bir ölçeğe rastlanılmamıştır. Bu yüzden, çalışmalarda, öğrencilerin asit-baz konusuna yönelik öz-yeterlik algılarını belirlemek için geçerli ve güvenilir bir ölçme aracına ihtiyaç olduğu düşünülmektedir. Illköğretim, lise ve üniversite kimya derslerinde önemli ve geniş bir yer tutan ve öğrencilerin günlük yaşamdaki bir takım olguları açıklayabilmelerini sağlayan asit-baz konusu (Yıldız, Yıldırım ve İlhan, 2006) kimya konularının pek çoğuyla ilişkili olduğundan bu konunun öğrenilmesinde yaşanılan zorluklar, diğer konuların anlaşılmasında da sıkıntılara sebep olmaktadır (Morgil, Yılmaz ve Cingör, 2002). Bu sebeple öğretmen adaylarının bir kimya konusu açısından öz yeterlik algılarının belirlenmesi düşünülmüş ve kimya konularından birisi olarak asit-baz konusu seçilmiştir.

\subsection{Amacı}

Bu çalışmanın amacı asit-baz konusuna yönelik öz-yeterlik algı ölçeğinin geliştirilmesi ve fen bilimleri öğretmen adaylarının asit-baz konusuna yönelik öz-yeterlik algılarının çeşitli değişkenler (Cinsiyet, Sınıf Düzeyi, Mezun Olunan Lise Türü, Genel Kimya-II ders başarısı) açısından incelenmesidir.

\section{YÖNTEM}

Mevcut araştırma iki aşamada gerçekleştirilmiştir. Birinci aşamada, 'Asit-Baz Konusuna Yönelik ÖzYeterlik Algı Ölçeği (ABÖAÖ)' nin geçerlik ve güvenirliği ortaya konulmuştur. Çalışmada geliştirilen ABÖAÖ beşli likert tipi (Kesinlikle katılmıyorum dan Kesinlikle Katılıyorum a doğru derecelenmiş olup) 14 maddeden oluşturulmuştur. Araştırmanın ikinci kısmında fen bilimleri öğretmen adaylarının asit-baz konusuna yönelik öz-yeterlik algıları çeşitli değişkenler açısından incelenmiştir. Araştırmanın gerçekleştirilmesinde tarama modeli kullanılmıştır. Büyük gruplardan bilgi toplamada ve bu bilgileri sunmada kullanılan tarama araştırmaları, grup ya da grupların belirlenen bazı özelliklerini tespit etmek için veri toplamayı amaçlayan araştırmalardır (Büyüköztürk, 2012; Gravetter \& Wallnau, 2016). ABÖAÖ geliştirilmesinde, ölçeğin güvenirlik ve geçerliğinin ortaya konulması için belirli basamaklar belirlenerek ve bu basamaklar takip edilmiştir (Karasar, 2006; Tavşancıl, 2014).

\section{1 Örneklem}

ABÖAÖ' nün güvenirlik ve geçerlik analizleri için, üç farklı devlet üniversitesinde 353 kadın, 100 erkek olmak üzere toplam 453 fen bilimleri öğretmen adayından veriler toplanmıştır (Tablo 1). Geçerlik ve güvenirliği sağlanan ABÖAÖ ile fen bilimleri öğretmen adaylarının asit-baz öz-yeterlik algı düzeyinin belirlenmesi için, rastgele seçilen sekiz devlet üniversitesinde öğrenim gören 1005 fen bilimleri öğretmen adayından veriler toplanmıştır. Tarama çalışması için veriler toplandıktan sonra, veriler kontrol edilmiş ve eksik veya hatalı dolduran 23 öğretmen adayının verileri analiz dışı tutulmuştur. Sonuç olarak 982 öğretmen adayının verileri araştırmaya dahil edilmiştir. Araştırmanın verileri 2014-2015 eğitim-öğretim yılının bahar döneminde toplanmıştır. Araştırma verilerinin toplandığı haftalarda birinci sınıfta bulunan öğretmen adayları henüz asit-baz konusunu işlememişlerdir. Araştırma grubunun demografik özellikleri Tablo 1 de gözükmektedir.

Tablo 1. Ölçek geliştirme ve tarama çalışmasında örneklemin demografik özellikleri

\begin{tabular}{lcc}
\hline Ölçek geliştirme için örneklem & & \\
\hline Cinsiyet & $f$ & $\%$ \\
Kadın & 353 & 77.9 \\
Erkek & 100 & 22.1 \\
Toplam & 453 & 100 \\
\hline
\end{tabular}




\begin{tabular}{|c|c|c|}
\hline Sınıf düzeyi & $f$ & $\%$ \\
\hline 1 & 125 & 27.6 \\
\hline 2 & 133 & 29.4 \\
\hline 3 & 101 & 22.3 \\
\hline 4 & 94 & 20.8 \\
\hline Toplam & 453 & 100 \\
\hline \multicolumn{3}{|c|}{ Tarama araştırması için örneklem } \\
\hline Cinsiyet & $f$ & $\%$ \\
\hline Kadın & 792 & 80.7 \\
\hline Erkek & 190 & 19.3 \\
\hline Toplam & 982 & 100 \\
\hline Sınıf düzeyi & $f$ & $\%$ \\
\hline 1 & 307 & 31.3 \\
\hline 2 & 262 & 26.7 \\
\hline 3 & 217 & 22.1 \\
\hline 4 & 196 & 20.0 \\
\hline Toplam & 982 & 100 \\
\hline Mezun olunan lise türü & $f$ & $\%$ \\
\hline Düz Lise & 604 & 61.5 \\
\hline Meslek Lisesi & 80 & 8.1 \\
\hline Anadolu Lisesi & 298 & 30.3 \\
\hline Toplam & 982 & 100 \\
\hline Genel Kimya II ders başarısı* & $f$ & $\%$ \\
\hline $0.00-0.99$ & 74 & 7.5 \\
\hline $1.00-1.99$ & 100 & 10.2 \\
\hline $2.00-2.99$ & 343 & 34.9 \\
\hline $3.00-4.00$ & 157 & 16.0 \\
\hline Toplam & 674 & 68.6 \\
\hline
\end{tabular}

*Birinci sınıf öğretmen adaylarının henüz notu belli olmadığı için örneklem azdır.

\subsection{Veri Toplama Süreci}

Bu çalışmada tarama araştırması için ABÖAÖ, 2014-2015 eğitim-öğretim yılının bahar döneminde sekiz farklı devlet üniversitesinde öğrenim gören toplam 982 fen bilimleri öğretmen adayından veriler toplanmıştır. Veri toplama aracı sınıflarda bizzat araştırmacının kendisi tarafından ya da üniversitelerde görevli öğretim elemanları tarafından uygulanarak elde edilmiştir. Uygulama yapılmadan öğretmen adaylarına, ölçeğin nasıl doldurulması gerektiği hakkında bilgiler verilmiştir. Öğretmen adayları ile ilgili bireysel değerlendirmeler yapılmayacağı bu sebeple kimlik bilgilerine intiyaç duyulmadığı örneklemdeki bireylere sözlü olarak bildirilmiştir. Ayrıca, öğretmen adaylarına araştırmaya katılımın gönüllülük esasına dayandığı ve istedikleri takdirde, araştırma tamamlandığında, araştırma sonuçları ve bulgular hakkında bilgi alabilecekleri bildirilmiştir. Ölçeğin uygulanmasında süre kısıtlamasına gidilmemiştir.

\subsection{Verilerin Analizi}

Araştırma kapsamında elde edilen verileri analiz etmek için "Microsoft Excel 2010" elektronik tablo programı, "IBM SPSS Statistics 20" ve "LISREL 8.7" istatistik programlarından yararlanılmıştır. Öncelikle ABÖAÖ ile toplanan verilerin, yapılacak olan istatistiksel tekniklerin varsayımlarını karşılaması adına puanların normal dağılım gösterip göstermediği araştırılmıştır. Öğretmen adaylarının asit-baz konusuna yönelik öz-yeterlik algı düzeylerinin cinsiyet değişkenine göre farkılık gösterip göstermediğini belirlemek amacıyla bağımsız örneklem t-testi kullanılmıştır. Öğretmen adaylarının sınıf düzeyi, mezun oldukları lise türü ve "Genel Kimya II" dersi başarısı değişkenleri açısından asit-baz konusuna yönelik öz-yeterlik algı düzeylerinde farklılaşma olup olmadığını belirlemek amacıyla tek yönlü varyans analizi (ANOVA) tekniği kullanılmıştır. Tek yönlü varyans 
analizi sonucunun önemli bulunduğu durumlarda farkın hangi ortalamalar arasındaki farklardan kaynaklandığını belirlemek için Tukey testi, homojen olmadığı durumlarda ise Dunnet $C$ testi yapılmıştır.

\subsection{Asit-Baz Öz-Yeterlik Algı Ölçeği (ABÖAÖ) nin Geliştirilmesi}

Bu çalışmada ABÖAÖ geliştirme sürecinde izlenen basamaklar alan yazından (Karasar, 2006; Tavşancıl, 2014) yararlanılarak aşağıdaki şekilde oluşturulmuştur:

Kapsam ve Görünüş Geçerliğinin Sağlanması için; a) ABÖAÖ’nün kuramsal çerçevesinin oluşturulması; b) Madde havuzunun oluşturulması; c) Uzman Görüşlerinin Alınması; d) Ön Uygulama Yapılması.

Yapı Geçerliğinin Sağlanması için; a) Madde analizi (Korelasyona dayalı madde analizi ve alt-üst grup ortalamaları farkına dayalı madde analizi; b) Açımlayıcı faktör analizi c) Faktörler arasındaki korelasyonel ilişkisi d) Faktör analizi sonrası madde toplam korelasyonu.

Güvenirlik Analizi için; i̇ç tutarlık katsayısı Cronbach's Alpha güvenirlik katsayısının hesaplanması.

\subsubsection{Kapsam ve Görünüş geçerliği}

\subsubsection{ABÖAÖ' nün kuramsal çerçevesinin oluşturulması}

ABÖAÖ' nün kuramsal çerçevesinin oluşturulması iki aşamada sağlanmıştır. İlk aşamada alan yazın taraması yapılarak öz-yeterlik algısı ile ilgili çalışmalar incelenmiştir (Bong, 1995; Buldur, 2009; Deniş ve Genç, 2010; Ekici, 2005; Elias, 2008; Gürbüzoğlu Yalmancı ve Aydın, 2014 Hızlıok, 2012; Karamustafaoğlu, Uluçınar Sağır ve Özkan, 2012; Köseoğlu, 2010; Sezgin Saf, 2011).

ìkinci aşama olarak, 60 fen bilimleri öğretmen adayının asit-baz konusu ile ilgili olarak yazılı görüşleri alınmıştır. Bu görüşler alınırken öğretmen adaylarından boş bir kağıda asit-baz ile ilgili olarak ne düşündüklerinin yazılması istenmiştir. Ayrıca, üç fen bilimleri öğretmen adayı ile yarı yapılandırımış mülakatlar gerçekleştirilmiştir. Yazılı görüşler ve mülakatlar ile öğretmen adaylarının asit-baz konusuna yönelik öz-yeterlik algılarını ortaya çıkaran temalar olarak; öğretmen adaylarının asit-baz konusunu günlük yaşamla ilişkilendirebilme yada ilişkilendirememe durumları, asit-baz konusu ile ilgili bilgisine yönelik durumlar, asit ve bazlarla ilgili uygulama ve açıklamalar yapabilme ya da yapamama durumları olarak belirlenmiştir.

Alan yazın taramalarından ve öğretmen adayları ile yapılan görüşmelerden elde edilen bilgiler göz önünde bulundurularak $A B O ̈ A O ̈ \prime$ nün kuramsal çerçevesi için iki boyut düşünülmüştür. Birinci boyut; "Günlük Yaşamla İlişkilendirme”; ikinci boyut; “Konu Hakkındaki Bilgi ve Bilimsel Açıklamalar Yapabilme" olarak adlandırılmıştır. Ölçekte madde yazımı bu çerçevede oluşturulmuştur.

\subsubsection{Madde havuzunun oluşturulması}

ABÖAÖ için, madde havuzu oluşturulurken, ölçeğin kuramsal çerçevesi göz önünde bulundurularak 10.Sınıf (MEB) Kimya Dersi Asitler, Bazlar ve Tuzlar ünitesinin kazanımları temel alınmıştır (MEB, 2013). Ayrıca, alan yazın taramaları ve öğretmen adaylarının görüşlerinden elde edilen verilerden de yararlanılarak da hazırlanan taslak ABÖAÖ için, ilk olarak 42 maddelik madde havuzu oluşturulmuştur.

\subsubsection{Uzman görüşlerinin alınması}

Taslak halindeki ABÖAÖ 'deki madde havuzunda yer alan maddelerin, fen bilgisi öğretmen adaylarının asit-baz konusuna yönelik öz-yeterlik algılarını ortaya çıkarabilmek için uygun maddeler olup olmadığı alanında uzman olarak kabul edilen 8 öğretim üyesi tarafından incelenmiştir. Bu öğretim üyelerinden, biri kimya alanında profesör doktor, biri kimya eğitimi alanında profesör doktor, ikisi kimya eğitimi alanında doçent doktor ve iki tanesi kimya alanında yardımcı doçent doktor ve ikisi kimya eğitimi alanında yardımcı doçent doktor unvanlarına sahiptir. Bu öğretim üyelerinin seçilmesinde, ölçek geliştirme çalışmalarında bulunmaları, fen veya kimya eğitimi alanında çalışmaları göz önünde bulundurulmuştur. Öğretim üyelerinin görüşleri, araştırmacı tarafından hazırlanan "Uzman Görüş Formu" kullanılarak, birebir görüşmeler (3 uzman ile) veya elektronik posta aracılı̆ııla (5 uzman ile) alınmıştır. Uzman görüş formunda uzmanlar her bir 
maddeyi inceleyerek, maddenin uygunluğu (uygun-düzeltilmesi gerek-çıkarılmalı şeklinde) ve kazanım açısından ilişkisi hakkındaki görüşlerini yazılı olarak ifade etmişlerdir. Uzman görüşleri sonunda ölçek madde sayısı 21'e düşürülmüştür. Ölçekteki maddelerin dili açısından açık, net, anlaşııır olması, maddelerin içeriklerinin uygunluğu gibi hususlarda alınan bu görüşlerle birlikte ölçekteki bazı maddelerde düzeltmeler yapılmıştır. Böylece, ölçeğin kapsam ve görünüş geçerlikleri sağlanmaya çalışılmıştır (Tavşancıl, 2014).

\subsubsection{4 Ön uygulama yapılması}

ABÖAÖ' nün kapsam ve görünüş geçerliğinin sağlanmasında ikinci bir uygulama olarak 40 fen bilimleri öğretmen adayına uygulama yapılmıştır ve bu uygulamanın sonuçlarına göre ölçeğin dili, anlaşılırlığı, uygulama süresi gibi durumlarla ilgili düzenlemelere gidilmiştir.

\subsubsection{Yapı Geçerliği}

\subsubsection{Madde Analizi}

ABÖAÖ' nün geliştirme çalışması kapsamında yapılan, "korelasyona dayalı madde analizi" ve "alt-üst grup ortalamaları farkına dayalı madde analizi" 21 madde üzerinden gerçekleştirilmiştir. ABÖAÖ' nün korelasyona dayalı madde analizini gerçekleştirme işlemi olarak ölçek maddelerinden elde edilen puanlar ile ölçek toplam puanı arasındaki korelasyon değerleri hesaplanmıştır (Tablo 2). Ölçek geliştirme çalışmalarında bir maddenin madde-toplam korelasyon değeri açısından kabul edilebilir olması için madde-toplam korelasyonun $0.25^{\prime}$ ten yüksek olması gerekmektedir (Özdamar, 2013). АВÖAÖ madde-toplam korelasyon değerleri 0.251 ile 0.681 arasında değişmektedir (Tablo 2).

Tablo 2. ABÖAÖ maddelerinin madde-toplam korelasyonları ve alt-üst grup ortalamalar arası t-testi sonuçları

\begin{tabular}{cccccc}
\hline $\begin{array}{c}\text { Madde } \\
\text { No }\end{array}$ & $\begin{array}{c}\text { Madde-toplam } \\
\text { Korelasyonları }(r)\end{array}$ & $\begin{array}{c}\text { Altlüst grup } \\
\text { ortalamalar } \\
\text { arası farkın t- } \\
\text { değeri }\end{array}$ & $\begin{array}{c}\text { Madde } \\
\text { No }\end{array}$ & $\begin{array}{c}\text { Madde-toplam } \\
\text { Korelasyonları }(r)\end{array}$ & $\begin{array}{c}\text { Altlüstgrup } \\
\text { ortalamalararası } \\
\text { farkın t-değeri }\end{array}$ \\
\hline 1 & $0.555^{* *}$ & 3.585 & 12 & $0.637^{* *}$ & 5.028 \\
2 & $0.466^{* *}$ & 3.680 & 13 & $0.561^{* *}$ & 6.665 \\
3 & $0.511^{* *}$ & 2.958 & 14 & $0.634^{* *}$ & 6.044 \\
4 & $0.568^{* *}$ & 7.186 & 15 & $0.544^{* *}$ & 6.908 \\
5 & $0.570^{* *}$ & 4.692 & 16 & $0.638^{* *}$ & 6.695 \\
6 & $0.526^{* *}$ & 4.239 & 17 & $0.572^{* *}$ & 4.936 \\
7 & $0.604^{* *}$ & 6.719 & 18 & $0.601^{* *}$ & 4.181 \\
8 & $0.251^{* *}$ & 4.832 & 19 & $0.660^{* *}$ & 5.215 \\
9 & $0.576^{* *}$ & 4.755 & 20 & $0.639^{* *}$ & 6.885 \\
10 & $0.681^{* *}$ & 4.898 & 21 & $0.625^{* *}$ & 5.401 \\
11 & $0.672^{* *}$ & 6.427 & & & \\
\hline
\end{tabular}

** $p<.01$

Alt-üst grup ortalamaları farkına dayalı madde analizinin gerçekleştirilmesinde, ölçek puanları büyükten küçüğe doğru sıralanmış ve puanların dağılımında üstten \% 27' lik kısım (123) ile alttan \% 27' lik kısım (123) puanları gruplanarak, her madde için üst gruptakilerin puan ortalamaları ile alt gruptakilerin puan ortalamaları arasındaki farkın t değeri hesaplanmıştır (Tablo 2).

\subsubsection{Açımlayıcı faktör analizi}

Açımlayıcı faktör analizinde ilk olarak Kaiser-Meyer-Olkin (KMO) testi ile örneklem yeterliliğine bakılmış ve Bartlett testi (Bartlett test of Sphericity) yapılarak verilerin faktör analizi yapmaya uygunluğu tespit edilmiştir. KMO değeri 0.922 bulunurken, Bartlett testi değeri ise 3117.683 olarak hesaplanmıştır. KMO değerinin 0.50 'den büyük olması ve Bartlett testinin ise anlamlı çıkması verilerin faktör analizi yapılması için uygunluğunu göstermektedir (Tabachnick \& Fidel, 2001). 
Tablo 3. Faktörlerin açıkladığı varyanslar ve öz değerler

\begin{tabular}{cccc}
\hline Faktör & Özdeğer & Varyans(\%) & Kümülatif(\%) \\
\hline 1 & 5.115 & 23.616 & 23.616 \\
2 & 1.425 & 23.097 & 46.713 \\
\hline
\end{tabular}

Ölçeğin faktör sayısı belirlenirken, özdeğer (eigenvalues) istatistiği, çizgi grafiği (scree plot) (Şekil 1) ve toplam varyansların yüzdesi yöntemi kullanılmıştır (Tablo 3). Faktörlerin rotasyonu yapılırken ise varimax tekniği kullanıımıştır. Faktör sayısı belirlenirken ölçekteki maddelerin öz değeri 1'den büyük olanların dikkate alınması gerektiği bilindiğinden (Büyüköztürk, 2012), 21 madde ile yapılan analizler ve çizgi grafiği (Şekil 1) incelenmiş, ölçek 2 faktörden oluşturulmuştur.

Madde Sayısı

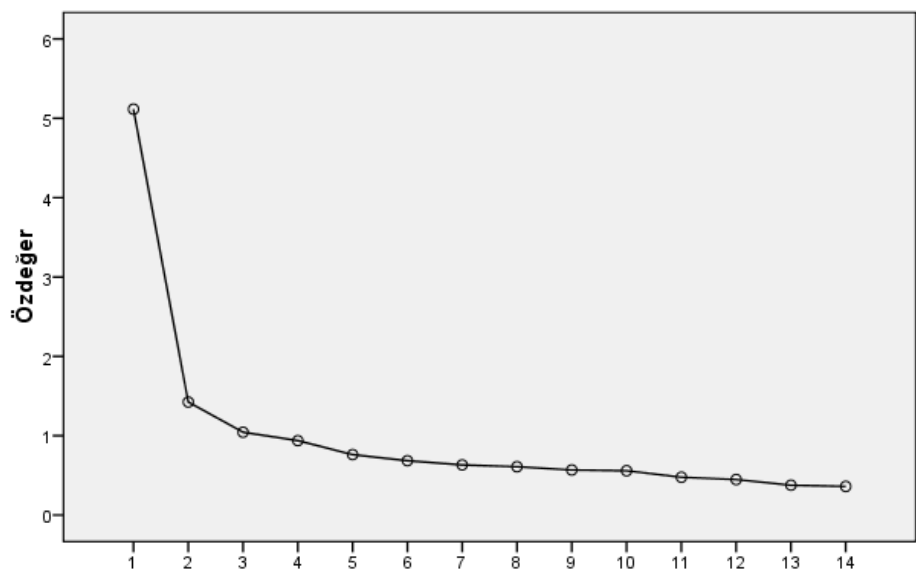

Şekil 1. ABÖAÖ için faktör analizi çizgi grafiği

Faktör sayısı belirlenen ölçek için, döndürülmüş faktör matrisi (Rotated Component Matrix) uygulanarak ve maddelerin her bir faktördeki yük değerleri incelenmiştir (Tablo 5). Her faktördeki maddeler belirlenirken, faktör yükleri 0.40 ve üzerinde olanlar uygun değerler olarak belirlenmiştir. Birden fazla faktör yüküne sahip olan bazı maddeler de alan yazındaki çalışmalarda (Bryman ve Cramer, 2001; Büyüköztürk, 2012) belirtildiği gibi ölçekten çıkarılmıştır. Bu ölçütlere dayanılarak 21 maddelik döndürülmüş faktör matrisi birkaç basamak devam ettirilmiş ve ölçekteki 3, 5, 6, 8, 10, 11 ve 14. maddeler çıkarılmıştır. Son haliyle 14 maddeden oluşan ölçeğin KMO değeri 0.887 iken, Bartlett's testi değeri ise 1933.104 bulunmuştur. 2 faktörlü 14 maddeden oluşan ölçeğin açıkladığı toplam varyans \% 46.713' tür (Tablo 3). Birinci faktör toplam varyansın \% 23.616'sını, ikinci faktör ise \% 23.097' sini açıklamaktadır. ABÖAÖ'nün maddelerinin faktör yük değerlerinin 0.512 ile 0.789 arasında değerler olduğu görülmektedir (Tablo 5).

\subsubsection{Faktörler arasındaki korelasyonel ilişki}

ABÖAÖ, iki faktörden oluşturulmuştur. Bu faktörler arasındaki ilişkinin ölçüsünü tespit etmek amacıyla Tablo 4' teki korelasyon değerlerine bakıldığında faktörler arasında orta düzeyde, pozitif ve anlamlı bir ilişki olduğu görülmektedir $\left(r_{12}=0.590, p<.05\right)$. Bu sonuca göre, boyutların ölçmek istediği özelliklerin olması gerektiği gibi farklı özellikleri ölçtüğü söylenebilir.

Tablo 4. ABÖAÖ' nün alt boyutları arasındaki korelasyonel ilişki

\begin{tabular}{llcc}
\hline & & Faktör 1 & Faktör 2 \\
\hline Faktör1 & Pearson Correlation & 1 & $0.590^{\star}$ \\
& P & & 0.000 \\
Faktör 2 & Pearson Correlation & - & 1 \\
$\mathrm{~N}$ & $\mathrm{P}$ & 453 & \\
\hline${ }_{\mathrm{k}}<.05$ & & &
\end{tabular}




\subsubsection{Faktör analizi sonrası madde toplam korelasyonu}

ABÖAÖ'nün son hali için elde edilen puanların madde-toplam korelasyonları hesaplanarak iç tutarlılığı incelenmiştir. Ölçekteki maddelerin, madde-toplam korelasyon değerleri 0.479 ile 0.661 arasında değişmektedir (Tablo 5).

\subsubsection{Güvenirlik analizi}

\subsubsection{Güvenirlik Katsayısının Hesaplanması}

453 fen bilimleri öğretmen adayına uygulanarak elde edilen puanların güvenirlik katsayısı (Cronbach's Alpha) tüm boyutlar için 0.864 olarak hesaplanırken; birinci faktördeki maddeler için, 0.776 iken ikinci faktördeki maddeler için 0.820 olarak hesaplanmıştır. Güvenirlik katsayılarının 0.70 'den büyük olması, puanların güvenilir olduğunu göstermektedir (DeVon ve diğerleri, 2007).

Tablo 5. ABÖAÖ' de yer alan maddelerin faktör yükleri, madde-toplam korelasyonları ve faktörlerin güvenirlik katsayıları

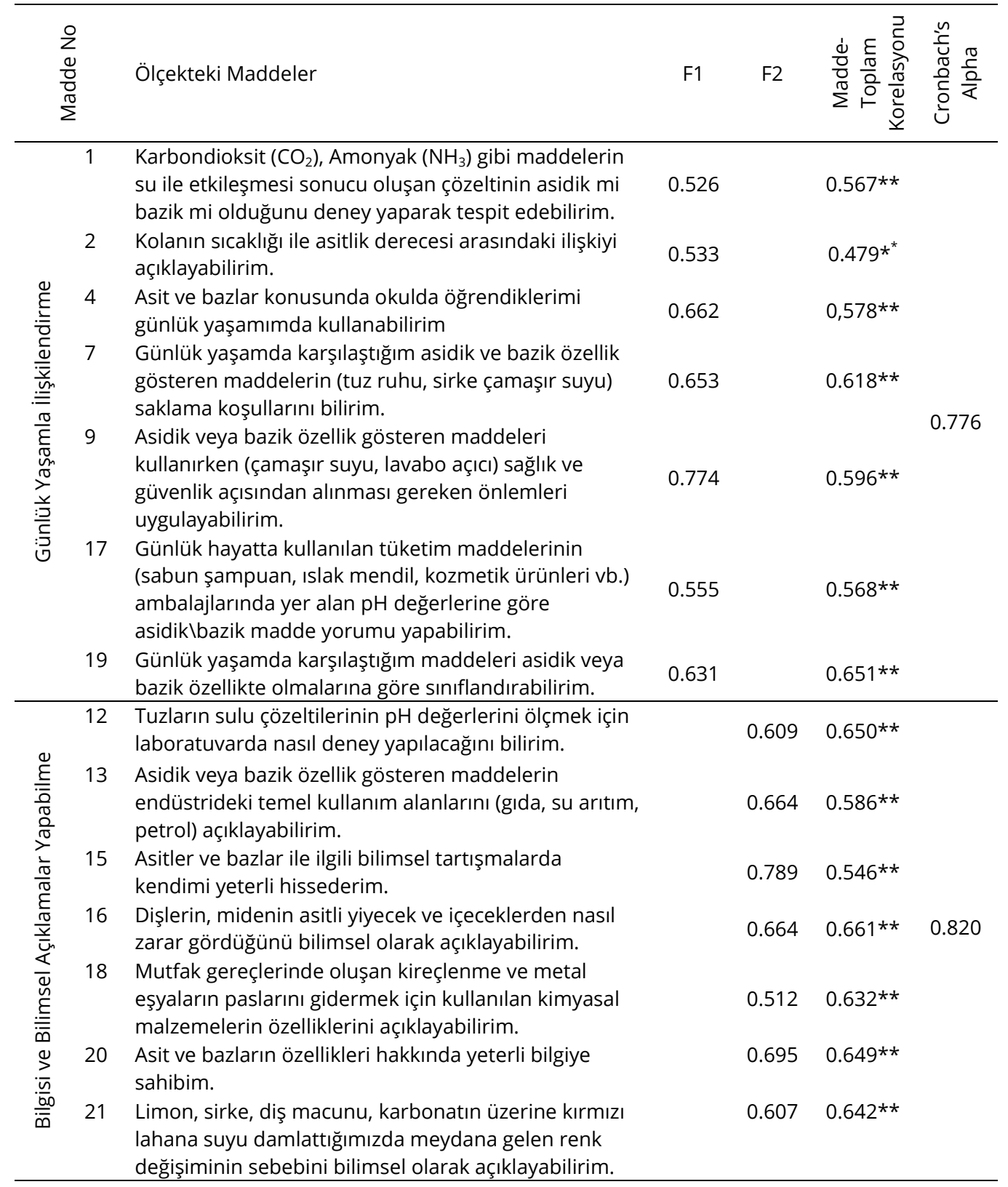




\section{BULGULAR}

\subsection{Tarama çalışmasındaki veriler için ABÖAÖ' nün Güvenirlik ve Geçerliği}

\subsubsection{Güvenirlik Katsayısı}

Tarama çalışmasında, 982 öğretmen adayından elde edilen verilerle güvenirlik katsayısı hesaplanmıştır. Elde edilen puanların güvenirlik katsayısı (Cronbach's Alpha) tüm boyutlar için 0.823 olarak hesaplanırken; birinci faktördeki maddeler için, 0.719 iken ikinci faktördeki maddeler için ise 0.762 olarak bulunmuştur (Tablo 6). Güvenirlik katsayılarının 0.70 'den büyük olması, puanların güvenilir olduğunu göstermektedir (Devon ve diğerleri, 2007).

Tablo 6. ABÖAÖ madde ortalamaları, madde standart sapmaları ve faktör bazında güvenirlik katsayısı

\begin{tabular}{cccc}
\hline No & Madde Ortalamaları & Madde Standart Sapmaları & Cronbach's Alpha \\
\hline 1 & 3.840 & 0.915 & \\
2 & 4.098 & 0.845 & \\
7 & 4.142 & 0.825 & \\
8 & 3.569 & 0.968 & 0.719 \\
12 & 4.070 & 0.787 & \\
13 & 3.990 & 0.829 & \\
14 & 3.995 & 0.807 & \\
\hline 3 & 3.668 & 0.845 & 0.762 \\
4 & 3.707 & 0.858 & \\
5 & 3.813 & 0.939 & \\
6 & 3.742 & 0.886 & \\
9 & 3.451 & 0.869 & 0.823 \\
10 & 3.681 & 0.882 & \\
11 & 3.281 & 0.882 & \\
& & Tüm maddeler için
\end{tabular}

\subsubsection{Doğrulayıcı Faktör Analizi}

Doğrulayıcı faktör analizi, belirlenen bir yapının doğrulanıp doğrulanmadığının sağlamasını yapmak için yapılır (Tabachnick \& Fidell, 2001). Bu çalışmada doğrulayıcı faktör analizleri LISREL 8.7 istatistik programı kullanılarak gerçekleştirilmiştir. Açımlayıc faktör analizine göre 14 madde ve iki faktörden oluşan ABÖAÖ' nün faktör yapısının doğruluğunun test edilmesi için tarama çalışmasından elde edilen verilerle doğrulayıc faktör analizi yapıımıştır (Tablo 7).

Tablo 7. ABÖAÖ' nün doğrulayıcı faktör analizi uyum indeksleri

\begin{tabular}{llllllllll}
\hline Analiz & $\mathrm{X}^{2}$ & $\mathrm{X}^{2} \backslash \mathrm{df}$ & RMSEA & RMR & SRMR & GFI & AGFI & NFI & CFI \\
\hline & 327.78 & 4.429 & 0.059 & 0.034 & 0.044 & 0.95 & 0.94 & 0.95 & 0.96 \\
\hline$X^{2} \backslash d f$ deg
\end{tabular}

$\mathrm{X}^{2} \backslash \mathrm{df}$ değeri 4.429 olduğu görülmektedir. Ki karenin serbestlik derecesine oranının 5 veya altında olması modelin uyum indeksinin kabul edilebilir olduğu bilinmektedir (Klem, 2000). Doğrulayıcı faktör analizinde modelin doğrulanmasında uyum indeklerine bakılır. Uyum indeksleri değerlerine bakıldığında RMSEA (Root Mean Square Error of Approximation) $=0.059$, RMR (Root Mean Square Residual $)=0.034$, SRMR (Standardized Root Mean Square Residual $)=0.044$ olarak bulunmuştur. Bu değerlerin 0.08'in altında olması gerekmektedir (Hu \& Bentler, 1999). Alanyazında (Hu \& Bentler, 1999; Hooper, Coughlan, \& Mullen, 2008 Tabachnick \& Fidell, 2001) 0.09 ile 1 arasında değer almasının iyi bir uyum indeksi olduğu belirtilen diğer indekslerden; GFI (Goodness of Fit Index )= 0.95, AGFI (Adjusted Goodness of Fit Index) $=0.94$, NFI (Normed Fit Index) $=0.95$, CFI (Comparative Fit Index) $=0.96$ olarak hesaplanmıştır (Tablo 7). Doğrulayıcı faktör analizi Path Diyagramı Şekil 2' de verilmiştir. 


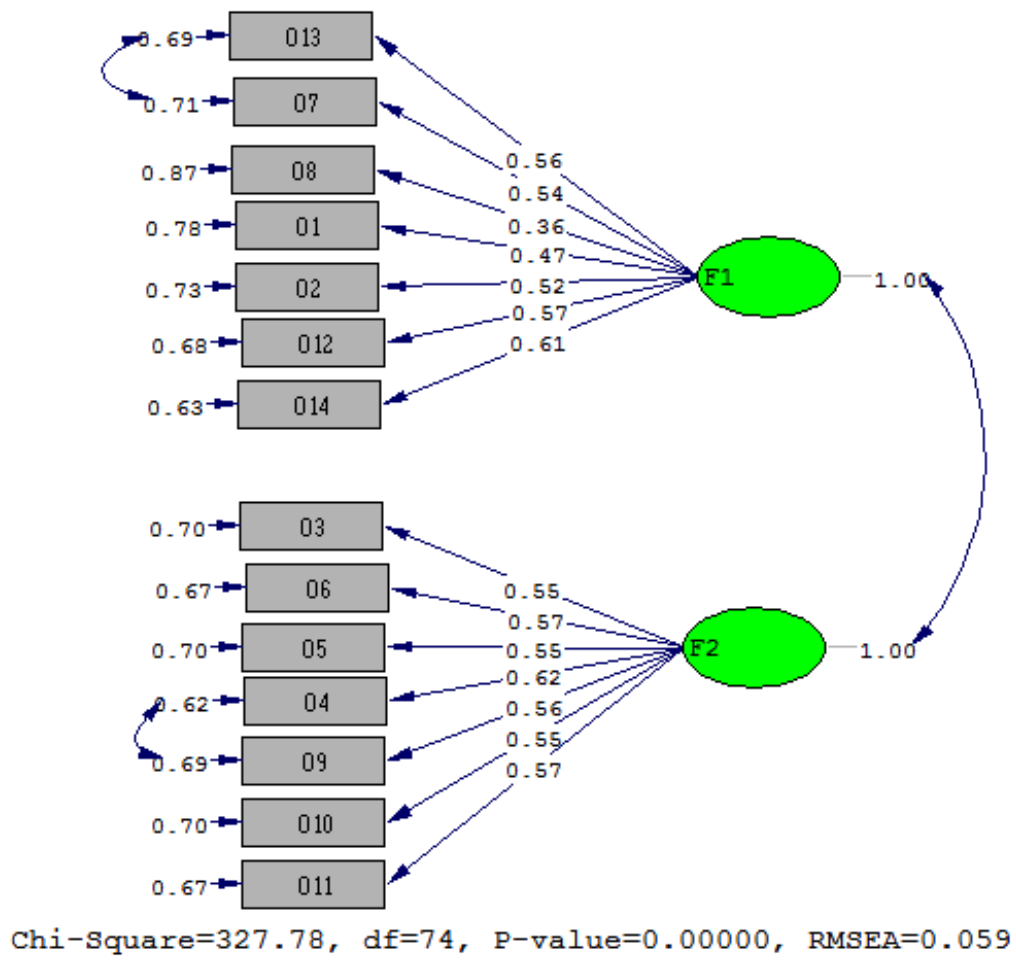

Şekil 2. ABÖAÖ için doğrulayııı faktör analizi path diyagramı

\subsection{Asit-Baz Konusuna Yönelik Öz-Yeterlik Algı Düzeylerini Betimlemeye İlişkin Bulgular}

ABÖAÖ' de yer alan maddelerin ortalamalarının 3.281 ile 4.142 arasında değiştiği görülmektedir (Tablo 6). En düşük madde ortalamasına sahip olan maddenin 11. madde "Asitler ve bazlar ile ilgili bilimsel tartışmalarda kendimi yeterli hissederim", en yüksek madde ortalamasına sahip olan maddenin ise 7. madde "Asidik veya bazik özellik gösteren maddeleri kullanırken (çamaşır suyu, lavabo açıcı) sağ ık ve güvenlik açısından alınması gereken önlemleri uygulayabilirim" olduğu görülmektedir.

ABÖAÖ' den elde edilen puanların ortalamaları 53.0468, standart sapma ise 6.69062 olarak hesaplanmıştır. ABÖAÖ için elde edilen puanların çarpıklık (skewness) katsayısı -0.126 iken basıklık (kurtosis) katsayısı ise, -0.289 olarak hesaplanmıştır. Bu değerler verilerin aşırı çarpıklık ve basıklık göstermediğini ifade etmektedir. ABÖAÖ'den alınabilecek en düşük puan 14, en yüksek puanın 70 olduğu dikkate alınırsa araştırmaya katılan öğretmen adaylarının asit-baz konusuna yönelik özyeterlik algılarının çoğunlukla yüksek düzeyde olduğu söylenebilir.

\subsection{Cinsiyetlerine Göre Asit-Baz Konusuna Yönelik Öz-Yeterlik Algı Düzeylerine iliş̧kin Bulgular}

Öğretmen adaylarının cinsiyetlerine göre asit-baz konusuna yönelik öz-yeterlik algı düzeyleri arasında anlamlı farkın olup olmadığı incelemek için bağımsız örneklem t -testi analizi yapılmıştır. Tablo 8 incelendiğinde, kadın ve erkek öğretmen adaylarının öz-yeterlik algı düzeyi puanları $\left(\mathrm{t}_{(980)}\right.$ =4.36, $\mathrm{p}<0.05$ ) arasında istatistiksel olarak anlamlı bir farklılık bulunmuştur. Bu farklılık erkek adayların asit-baz konusuna yönelik öz-yeterlik algı düzeyi puan ortalamalarının $(\bar{X}=51.16$, s $=$ $6,88)$, kadın adayların asit-baz konusuna yönelik öz-yeterlik algı düzeyi puan ortalamalarından $(\bar{X}=$ 53.50, s= 6.57) daha düşük olmasından kaynaklanmaktadır. Bu durumda araştırmanın veri grubunda yer alan kadın öğretmen adaylarının asit-baz konusuna yönelik öz-yeterlik algı düzeylerinin erkek öğretmen adaylarından anlamlı olarak yüksek olduğu söylenebilir. 
Tablo 8. Cinsiyetlere göre bağımsız örneklem t -testi sonuçları

\begin{tabular}{llllllll}
\hline Değişken & Cinsiyet & $\mathrm{N}$ & $\bar{X}$ & $\mathrm{~s}$ & $\mathrm{t}$ & $\mathrm{sd}$ & $\mathrm{p}$ \\
\hline Öz-Yeterlik Algı & Kadın & 792 & 53.50 & 6.57 & \multirow{2}{*}{4.36} & \multirow{2}{*}{980} & \multirow{2}{*}{0.000} \\
Düzeyi & Erkek & 190 & 51.16 & 6.88 & & & \\
\hline
\end{tabular}

3.4 Sınıf Düzeyi, Mezun Olunan Lise Türü ve Genel Kimya II Dersi Başarılarına Göre Asit-Baz Konusuna Yönelik Öz-Yeterlik Algı Düzeylerine İlişkin Bulgular

Öğretmen adaylarının öz-yeterlik algı düzeyleri eğitim gördükleri sınıf düzeyi açısından değerlendirildiğinde (Tablo 9); üçüncü sınıftaki öğretmen adayları en yüksek öz-yeterlik algı düzeyi ortalamasına sahipken, en düşük öz-yeterlik algı düzeyi ortalamasına ise birinci sınıftaki öğretmen adayları sahiptir. Mezun olunan lise türü açısından ise; meslek lisesinden mezun olan öğretmen adayları en yüksek öz-yeterlik algı düzeyi ortalamasına sahip iken anadolu lisesinden mezun olan öğretmen adaylarının ise en düşük öz-yeterlik algı düzeyine sahip olduğu görülmüştür. Öğretmen adaylarının asit-baz konusunun da işlendiği Genel Kimya II not ortalaması açısından öz yeterlik algı düzeyleri incelendiğinde; 3.00-4.00 aralığında olan öğretmen adayları en yüksek öz-yeterlik algı düzeyi ortalamasına sahipken, not ortalaması 0.00-0.99 aralığında olan öğretmen adaylarının ise en düşük öz-yeterlik algı düzeyi ortalamasına sahip oldukları görülmüştür.

Tablo 9. Sınıf düzeyi, mezun olunan lise türü ve Genel Kimya II Dersi başarısı açısından ABÖAÖ’den elde edilen betimsel sonuçlar

\begin{tabular}{lccc}
\hline Sınıf Düzeyi & $\mathrm{N}$ & $\bar{X}$ & $\mathrm{~s}$ \\
\hline 1.Sınıf & 307 & 51.83 & 14.30 \\
2.Sınıf & 262 & 53.90 & 13.17 \\
3.Sınıf & 217 & 54.06 & 12.23 \\
4.Sınıf & 196 & 52.68 & 13.53 \\
Toplam & 982 & 53.05 & 13.46 \\
\hline Mezun Olunan Lise Türü & & & \\
\hline Anadolu Lisesi & 298 & 52.75 & 6.91 \\
Meslek Lisesi & 80 & 53.27 & 6.53 \\
Düz Lise & 604 & 53.16 & 6.61 \\
Toplam & 982 & 53.05 & 6.69 \\
\hline Genel Kimya II Ders Başarısı & & & \\
(4'lük Sistem)* & & & 6.21 \\
\hline 0- 0,99 & 74 & 52.19 & 5.67 \\
1,00-1,99 & 100 & 52.72 & 6.54 \\
2,00- 2,99 & 343 & 53.57 & 6.57 \\
3,00-4,00 & 157 & 54.92 & 6.44 \\
Toplam & 674 & 53.61 & \\
\hline
\end{tabular}

*"Genel Kimya II" Ders başarısı verileri, ölçeğin geliştirildiği dönemde birinci sınıf öğretmen adayları için henüz belirlenmediğinden ikinci, üçüncü ve dördüncü sınıflardan toplanmıştır.

Fen bilimleri öğretmen adaylarının sınıf düzeyi, mezun olunan lise türü ve "Genel Kimya II" dersi başarılarına göre asit-baz konusuna yönelik öz-yeterlik algı düzeyleri puan ortalamaları arasındaki bu farkların anlamlı olup olmadığını belirlemeye yönelik ANOVA testi yapılmıştır (Tablo 10). 
Tablo 10. ANOVA sonuçları

\begin{tabular}{|c|c|c|c|c|c|c|}
\hline & $\begin{array}{l}\text { Varyansın } \\
\text { Kaynağı }\end{array}$ & Kareler Toplamı & sd & $\begin{array}{c}\text { Kareler } \\
\text { Ortalaması }\end{array}$ & $\mathrm{F}$ & $p$ \\
\hline \multirow{3}{*}{ Sınıf Düzeyi } & $\begin{array}{l}\text { Gruplar } \\
\text { arası }\end{array}$ & 895,749 & 3 & 298.583 & 6.788 & 0.000 \\
\hline & Gruplar içi & 43018,097 & 978 & 43.986 & & \\
\hline & Toplam & 43913,845 & 981 & & & \\
\hline \multirow{3}{*}{$\begin{array}{l}\text { Mezun } \\
\text { Olunan Lise } \\
\text { Türü }\end{array}$} & $\begin{array}{l}\text { Gruplar } \\
\text { arası }\end{array}$ & 38,172 & 2 & 19.086 & 0.426 & 0.653 \\
\hline & Gruplar içi & 43875,673 & 979 & 44,817 & & \\
\hline & Toplam & 43913,845 & 981 & & & \\
\hline \multirow{3}{*}{$\begin{array}{l}\text { Genel Kimya } \\
\text { II Dersi } \\
\text { Başarısı }\end{array}$} & $\begin{array}{l}\text { Gruplar } \\
\text { arası }\end{array}$ & 497,446 & 3 & 165.815 & 4.064 & 0.007 \\
\hline & Gruplar içi & 27335,575 & 670 & 40.799 & & \\
\hline & Toplam & 27833,021 & 673 & & & \\
\hline
\end{tabular}

Tablo 10' incelendiğinde ANOVA sonucunda, öğretmen adaylarının sınıf düzeylerine göre öz-yeterlik algı düzeyi puan ortalamaları arasında istatistiksel olarak anlamlı bir farklıık olduğu görülmüştür $\left(F_{3-978}=6.788, p<.05\right)$. Anlamlı farklıığın hangi gruplar arasından kaynaklandığını belirlemek amacıyla yapılan Dunnett $C$ çoklu karşılaştırma testine göre birinci sınıf öğretmen adaylarının asitbaz konusuna yönelik öz-yeterlik algı düzeylerinin, ikinci ve üçüncü sınıf öğretmen adaylarının asitbaz konusuna yönelik öz-yeterlik algı düzeylerinden anlamlı düzeyde daha düşük olduğu görülmüştür.

Mezun oldukları lise türüne göre öğretmen adaylarının asit-baz öz-yeterlik algı düzeyi puanları arasında istatistiksel olarak anlamlı bir farklılık olmadığı görülmüştür $\left(F_{2-979}=0.426, p>.05\right)$.

"Genel Kimya II" dersi başarılarına göre öğretmen adaylarının asit-baz öz-yeterlik algı düzeyi puanları arasında istatistiksel olarak anlamlı bir farklılık olduğu görülmüştür $\left(F_{3-670}=4.064, p<0.05\right)$. Anlamlı farklılığın hangi gruplar arasından kaynaklandığını belirlemek amacıyla yapılan Dunnett $C$ çoklu karşılaştırma testine göre, Genel Kimya II başarısı "0-0.99" ve "1-1.99" olan öğretmen adaylarının asit-baz konusuna yönelik öz-yeterlik algı düzeylerinin Genel Kimya II başarısı "3.004.00" olan öğretmen adaylarının asit-baz konusuna yönelik öz-yeterlik algı düzeylerinden anlamlı düzeyde daha düşük olduğu görülmüştür.

\section{SONUÇ VE ÖNERILER}

Bu çalışma kapsamında beşli likert türü ve 14 maddeden oluşan ABÖAÖ’ nün güvenirlik ve geçerliği ortaya konulmuştur. Güvenilirliği ve geçerliği ortaya konulan ABÖAÖ aracılığıyla 982 fen bilimleri öğretmen adayı ile tarama çalışması gerçekleştirilmiştir. Tarama çalışmasında elde edilen veriler içinde güvenirlik ve geçerlik çalışması tekrar yapılmıştır. ABÖAÖ iki boyutta oluşturulmuştur. Boyutlar "Günlük Yaşamla İlişkilendirme", "Konu Hakkındaki Bilgi ve Bilimsel Açıklamalar Yapabilme" olarak adlandırılmıştır. Bu çalışmada ABÖAÖ'nün maddelerinin geliştirilmesinde MEB (2013) kazanımları dikkate alınmıştır. Son yıllarda konuların günlük yaşam ile ilişkilendirilerek öğretimi önem kazanmaktadır (ilhan, Doğan ve Çiçek, 2015),

Bu çalışmanın araştırma sonuçları, kadın fen bilimleri öğretmen adaylarının asit-baz konusu özyeterlik algı puanlarının erkek fen bilimleri öğretmen adaylarının asit-baz konusu öz-yeterlik algı puanlarından anlamlı düzeyde daha yüksek olduğunu göstermektedir. Bu sonuç, kadın öğretmen adaylarının, asit-baz ile ilgili olarak bir öğretmenin yerine getirmesi gerekenler konusunda kendisini erkek adaylardan daha yeterli olarak algıladıklarını ifade etmektedir. Alan yazında asit-baz konusuna yönelik öz yeterliği ortaya koyan çalışmalara ulaşılmamakla birlikte benzer diğer çalışmalar incelendiğinde; bu araştırma sonucu, Britner \& Pajares (2001)' in, öğrencilerin fen bilgisi dersindeki motivasyonuna etki eden değişkenlerden biri olarak öz-yeterlik algısını ele aldığı 
çalışmasıyla, Özenoğlu Kiremit ve Gökler (2010)' in fen bilgisi öğretmen adaylarının biyoloji öğretimine yönelik öz-yeterlik algılarını inceledikleri çalışmalarıyla paralellik göstermektedir. Alan yazında öz-yeterlik algısının cinsiyete göre farklılaşmadığını gösteren çalışmalara da (Akkoyunlu ve Orhan, 2003; Çetin, 2008; Elias, 2008) rastlanmıştır. Ayrıca, erkeklerin öz-yeterlik algısının kadınlardan daha yüksek olduğu çalışmalar da (O'leary, 2005; Satıcı, 2013; Smist,1993) alanyazında mevcuttur. Bu bağlamda öz-yeterlik algısının cinsiyet değişkenine göre incelendiği çalışmalarda tam bir tutarlılık gözlendiği söylenemez. Bu durumun sebeplerinden biri, veri toplanan bireylerin yetiştirildiği ve bulunduğu ortamların, kişisel özelliklerinin farklı olması olabilir. Bazı kültürlerde, günlük yaşamda kadınlar daha fazla rol üstlenirken bazı kültürlerde ise tam tersi durum söz konusudur.

Mevcut araştırma sonuçları fen bilimleri öğretmen adaylarının öğrenim gördükleri sınıf düzeylerine göre asit-baz konusu öz-yeterlik algı düzeyleri arasında anlamlı bir farklılık olduğunu göstermektedir. Bu fark, birinci sınıf öğretmen adayları ile, ikinci ve üçüncü sınıf öğretmen adayları arasında oluşmuştur. Bu durumun sebepleri arasında, sınıf düzeyi arttıkça adayların öğrenim süreçlerinde kimya (dolayısıyla asit-baz konusu) ve öğretmenlik uygulamaları ile ilgili aldıkları derslerin yoğunlaşmasından kaynaklı olması gösterilebilir. Sınıf düzeyi arttıkça, adayların alanları bakımından öz-yeterliklerini geliştirebilecekleri uygulamalara (Fen Öğretimi Laboratuvar Uygulamaları, Özel Öğretim Yöntemleri vb.) dayalı dersleri daha fazla yoğunlaştığından, ikinci ve üçüncü sınıftaki adayların öz-yeterlik algıları daha yüksektir denilebilir. İkinci ve üçüncü sınıftaki öğretmen adaylarının, alanları ile ilgili deneyimlerinin birinci sınıftaki adaylardan daha fazla olması da bu sonucun sebeplerinden olabilir. Schunk ve Pajares (2001)' in çalışmalarında okul müfredatında yer alan kazanımların sınıf düzeyi ile birlikte arttığı ve böylece sınıf düzeyi arttıkça bu kazanımların öğrencilere verildiği, bu durumun da öğrencilerin öz-yeterlik algılarını arttırmasını sağladığını savunmuşlardır. Bu bilgilerden yola çıkılarak alan bilgisi ile öz-yeterlik algısı arasında paralel bir ilişki olduğunu söylenebilir. Ayrıca, çalışmanın uygulandığı dönemde birinci sınıf öğretmen adaylarının asit-baz konusu ile ilgili öğrenme süreçlerini tamamlamamış olmaları da özyeterlik algılarının düşük çıkmasına neden olmuş olabilir. Dördüncü sınıf öğretmen adaylarının, özyeterlik algı puanlarının düşük olmamasına rağmen diğer sınıflardan anlamlı olarak yüksek çıkmamasının sebebi ise, adayların KPSS (Kamu Personeli Seçme Sınavı)'ye yoğunlaştıkları bir dönemde olmaları olabilir. Adaylar bu süreçte, alan sınavına girecek olmalarının verdiği stresle başa çıkmaya çalıştıklarından kendilerini bir konu ya da dersle ilgili olarak yeterli görmemiş olabilirler. Öğretmenlik mesleğine ilk adımı attıkları okul deneyimi uygulamalarında ise deneyimsizlikten kaynaklı olarak yaşamış olabilecekleri birtakım problemler de adayların öz-yeterlik algılarını olumsuz etkilemiş olabilir. Ayrıca, Türkiye'de üniversitelerdeki programlarda dördüncü sınıf öğretmen adaylarının, lisans öğrenimlerinin son yılında, alanla ilgili teorik derslerden ziyade özelleşmiş konuları barındıran (Biyolojide Özel Konular, Evrim, Astronomi vb.) ya da öğretmenliğe başladıklarında kullanabilecekleri bilgilere yönelik (Sınıf Yönetimi, Rehberlik, Öğretmenlik Uygulaması vb.) derslerle karşılaşmaları, spesifik olarak belirlenen asit-baz öz-yeterlik algı ölçeğini yanıtlandıırken kendilerini düşük olarak algılamalarına neden olmuş olabilir. Araştırma sonucu, Özenoğlu Kiremit ve Gökler (2010)' in fen bilgisi öğretmen adaylarının biyoloji öğretimine yönelik öz-yeterlik algılarını inceledikleri çalışmalarıyla, Karaduman ve Emrahoğlu (2011)'nun sınıf öğretmenliği öğrencilerinin fen öğretimi öz-yeterlik algılarını incelediği çalışmalarıyla paralellik göstermektedir. Öz-yeterlik algısının sınıf düzeyleri değişkeni açısından incelendiği çalışmalara bakıldığında farklı sonuçlara ulaşıldığı da görülmektedir. Fırat Durdukoca (2010) ve Satıcı (2013), araştırmalarında ikinci sınıftaki öğretmen adaylarının diğer sınıf düzeylerine göre daha düşük özyeterlik algısına sahip oldukları sonucuna ulaşırlarken; Gürbüzoğlu Yalmancı ve Aydın (2014) ise, üçüncü ve dördüncü sınıftaki öğretmen adaylarının en yüksek öz-yeterlik algısına sahip oldukları sonucuna ulaşmışlardır. Ayrıca, öz-yeterlik algısının sınıf düzeylerine göre farklılaşmadığını gösteren çalışmalara da (Akkoyunlu ve Orhan, 2003; Karamustafaoğlu, Uluçınar Sağır ve Özkan, 2012) rastlanmıştır. 
Mevcut çalışma sonuçları, ABÖAÖ ile toplanan veriler fen bilimleri öğretmen adaylarının mezun oldukları lise türüne göre asit-baz konusuna yönelik öz-yeterlik algı düzeylerinin anlamlı bir farklıık göstermediğini ortaya koymaktadır. Bu sonuç, öğretmen adaylarının eğitim fakültelerinde öğrenim görmeye başlamaları sonucu öğretmenlik mesleği ve buna bağlı olarak mesleğin gerektirdiklerine karşı birbirine yakın bir tutum içerisine girmelerinden kaynaklı olabilir. Ayrıca, adaylar her ne kadar farklı lise türlerinde öğrenim görmüş olsalar da, lisans eğitimlerinde aynı bölümde ve aynı eğitim programında yetiştirilmeleri de anlamlı bir fark çıkmamasındaki etkenlerden birisi olabilir. Araştırma sonucu, Çetin (2008)' in sınıf öğretmenliği bölümü öğrencilerinin fen öğretimine yönelik öz-yeterlik algılarını incelediği çalışmasıyla, Özdemir (2008)'in sınıf öğretmenliği bölümü öğrencilerinin öğretime yönelik öz-yeterlik algılarının incelediği çalışmasıyla, Deniş ve Genç (2010)' in fen bilgisi öğretmen adaylarının fen öğretimine yönelik öz-yeterlik algılarının incelendiği çalışmalarıyla, Ekici (2012)' nin, sınıf yönetimi dersinin öğretmen adaylarının öğretmen öz-yeterlik algılarına etkisini incelediği çalışmasıyla, paralellik göstermektedir. Öz-yeterlik algısının mezun oldukları lise türü değişkeni açısından incelendiği çalışmalara bakıldığında farklı sonuçlara ulaşıldığı da görülmektedir. Meslek liseleri ve genel liselerden mezun olan öğrencilerin diğer lise türlerinden mezun olan öğrencilerden daha yüksek öz-yeterlik algısına sahip oldukları sonucuna ulaşan Akkoyunlu ve Orhan (2003)' ın çalışmasına ek olarak, yabancı dil ağırlıklı liseden mezun olan öğrencilerin genel liseden mezun olan öğrencilerden daha yüksek bir öz-yeterlik inancına sahip oldukları sonucuna ulaşan Karaduman ve Emrahoğlu (2011)' nun çalışmaları bunlara örnek olarak verilebilir.

Bu çalışmada ABÖAÖ ile toplanan verilerden fen bilimleri öğretmen adaylarının "Genel Kimya II" dersi başarılarına göre asit-baz öz-yeterlik algı düzeyleri incelendiğinde ortaya çıkan diğer bir sonuç ise; "Genel Kimya II" başarısı yüksek olan öğretmen adaylarının asit-baz öz-yeterlik algı puanlarının, "Genel Kimya II" başarısı düşük olan öğretmen adaylarının asit-baz öz-yeterlik algı puanlarından anlamlı olarak yüksek olmasıdır. Asit-baz ünitesinin "Genel Kimya II" dersi kapsamında, fen bilimleri öğretmen adaylarına verildiği göz önünde bulundurulduğunda, bu dersteki başarısı yüksek olan öğretmen adaylarının, öz-yeterlik algılarının da buna paralel olarak yüksek çıktığı söylenebilir. O halde, bireylerin akademik anlamdaki başarı düzeyleri, onların öz-yeterlik algılarını etkileyen değişkenler arasındadır denilebilir. Alanyazında, bu değişkene yakın olarak kabul edebileceğimiz, öz-yeterlik algısı ve akademik başarı değişkenini ele alan araştırmalar incelendiğinde bireylerin akademik başarıları ile öz-yeterlik algıları arasında pozitif yönde bir ilişki olduğu sonucuna varan çalışmalar bulunmaktadır (Ekici, 2012; Fettahlıoğlu, Güven, İnce Aka, Sert Çıbık ve Aydoğdu, 2011; Satıcı, 2013).

\section{5. ÖNERILER}

Mevcut çalışmada fen bilimleri öğretmen adaylarının öz yeterlik algı düzeylerini ölçen ABÖAÖ geliştirilmiş ve tarama çalışması ile bazı değişkenler açısından asit-baz öz yeterlik algı düzeyleri belirlenmiştir. Öğretmen adaylarının öz-yeterlik algılarının öğrenme-öğretme sürecindeki yerinin önemi göz önünde bulundurularak, farklı konu ve ünitelerde öğretmen adaylarının öz-yeterlik algılarının belirlenmesine yönelik çalışmalar artırılabilir. Öğretmen adaylarının öz-yeterlik algı düzeylerinin ölçülmesinin yanı sıra öğretmen ve öğrencilerin de öz yeterlik algı düzeylerinin ölçülmesi ve geliştirilmesine yönelik çalışmalar yapılabilir. Eğitim programlarının düzenlenmesinde öğretmen, öğretmen adayı ve öğrencilerin öz yeterlik algıları dikkate alınarak buna yönelik düzenlemeler yapılabilir. Öz-yeterlik algıları bireysel olduğu için öğretmen adaylarına ve öğrencilere, öğrenme sürecinde, bireylerin öz-yeterlik algılarının gelişmesine katkı sağlamak amacıyla, derslerde farklı eğitim yaklaşımlarına yer verilmesi önerilebilir. 


\section{Kaynakça}

Akkoyunlu, B. ve Orhan, F. (2003). Bilgisayar ve öğretim teknolojileri eğitimi (BÖTE) bölümü öğrencilerinin bilgisayar kullanma öz yeterlik inancı ile demografik özellikleri arasındaki ilişki. The Turkish Online Journal of Educational Technology 2(3), 11-20.

Aydın, N. (2008). "Sınıf Öğretmeni Adaylarının ve Öğretmenlerinin Çevre Eğitimine Yönelik Öz-yeterlik Inançları Üzerine Sınıf Düzeyi, Kıdem ve Değer Yönelimlerinin Etkisi". Yayınlanmamış Yüksek Lisans Tezi, Adnan Menderes Üniversitesi, Sosyal Bilimler Enstitüsü.

Bandura, A. (1977). Self-efficacy: toward a unifying theory of behavioral change. Psychological Review, 84(2), 191.

Bandura, A. (1986). The explanatory and predictive scope of self-efficacy theory. Journal of social and clinical psychology, 4(3), 359-373.

Bandura, A. (1989). Self-regulation of motivation and action through internal standards and goal system, in: Pervin, L.A. (Ed.), Goal Concepts in Personality and Social Psychology Hillsdale, NJ: Erlbaum. pp. 19-85.

Bandura, A. (1997). Self efficacy: the exercise of control. New York: Freeman.

Bong, M. (1995). "Epistemological Beliefs And Generalizability of Self-Efficacy: Implications For instructional Design". Yayınlanmamış Doktora Tezi, University of Southern California, California.

Britner, L. S. ve Pajares, F. (2001). Self-efficacy beliefs, motivation, race, and gender in middle school science. University Journal of Women and Minorities in Science andEngineering. 7, 271-285.

Bryman, A. ve Cramer, D., (2001). Quantitative data analysis with spss release 10 for windows. New York: Routledge.

Buldur, S. (2009). “Fen Bilgisi Öğretmen Adaylarının Alternatif Ölçme ve Değerlendirme Yaklaşımlarına Yönelik Okuryazarlık ve Öz Yeterlik Düzeylerinin Geliştirilmesi". Yayınlanmamış Yüksek Lisans Tezi, Cumhuriyet Üniversitesi, Sosyal Bilimler Enstitüsü.

Büyüköztürk, Ş. (2012). Sosyal bilimler için veri analizi el kitabı. Ankara: Pegem A Yayıncılık.

Çetin, B. (2008). Fen bilgisi öğretimi dersinin sınıf öğretmenliği anabilim dalı 3. sınıf öğrencilerinin fen öğretimindeki öz-yeterlik inançlarına etkisi. Dokuz Eylül Üniversitesi Sosyal Bilimler Enstitüsü Dergisi, 10(2), 55-71.

Deniş, H. ve Genç, H. (2010). Fen bilgisi öğretmen adaylarının öz-yeterlik inançlari ve çoklu zeka alanları. e-Journal of New World Sciences Academy Education Sciences, 5(3), 775-791.

DeVon, H. A., Block, M. E., Moyle-Wright, P., Ernst, D. M., Hayden, S. J., Lazzara, D. J. ve KostasPolston, E. (2007). A psychometric toolbox for testing validity and reliability. Journal of Nursing Scholarship, 39(2), 155-164.

Ekici, G. (2005). Biyoloji öz-yeterlik ölçeğinin geçerlik ve güvenirliği. Hacettepe Üniversitesi Eğitim Fakültesi Dergisi, 29, 85-94.

Ekici, G. (2012). Sınıf yönetimi dersinin öğretmen adaylarının öğretmen öz-yeterlik algı düzeyine etkisi. Hacettepe Üniversitesi. Eğitim Fakültesi Dergisi, 35, 98-110.

Elias, R. Z. (2008). Anti-intellectual attitudes and academic self-efficacy among business students. Journal of Education for Business, 84(2),110-117.

Fettahlıoğlu, P., Güven, E., İnce Aka, E., Sert Çıbık, A. ve Aydoğdu, M., (2011). Fen bilgisi öğretmen adaylarının fen öğretimine yönelik öz-yeterlik inançlarının akademik başarı üzerine etkisi. Kırşehir Üniversitesi Eğitim Fakültesi Dergisi, 12(3), 159-175.

Fırat Durdukoca, ş. (2010). Sınıf öğretmeni adaylarının akademik özyeterlik algılarının çeşitli değişkenler açısından incelenmesi. Abant Izzet Baysal Üniversitesi Eğitim Fakültesi Dergisi, 10(1), 69-77. 
Gravetter, F. J. ve Wallnau, L. B. (2016). Statistics for the behavioral sciences. Cengage Learning.

Gürbüzoğlu Yalmancı, S. ve Aydın, S., (2014). Fen bilgisi öğretmen adaylarının akademik öz-yeterlik algılarının incelenmesi. e-Kafkas Eğitim Araştırmaları Dergisi, 1(1), 60-66.

Gürlen, E. (2011). Probleme dayalı öğrenmenin öğrenme ürünlerine, problem çözme becerisine, özyeterlik algı düzeyine etkisi. Hacettepe Üniversitesi Eğitim Fakültesi Dergisi, 40(40).

Hızlıok, A. (2012). "ilköğretim Birinci Kademe 4. Sınıf Fen ve Teknoloji Dersinde Uygulanan Bilimsel Süreç Becerileri Temelli Etkinliklerin Öğrencilerin Fen ve Teknoloji Özyeterliklerine ve Akademik Başarılarına Etkisi". Yayınlanmamış Yüksek Lisans Tezi, Niğde Üniversitesi, Eğitim Bilimleri Enstitüsü.

Hooper, D., Coughlan, J. ve Mullen, M.R. (2008). Structural equation modelling: Guidelines for determining model fit. The Electronic Journal of Business Research Methods, 6(1), 53-60.

Hu, L. T. ve Bentler, P. M. (1999). Cut off criteria for fit indexes in covariance structure analysis: Conventional criteria versus new alternatives. A Multidisciplinary Journal, 6(1), 1-55.

İlhan, N., Doğan Y. ve Çiçek, Ö. (2015). Fen bilimleri öğretmen adaylarının "özel öğretim yöntemleri" dersindeki yaşam temelli öğretim uygulamaları. Bartın Üniversitesi Eğitim Fakültesi Dergisi, $4(2), 666-681$.

Karaduman, B. ve Emrahoğlu, N. (2011). Sınıf öğretmeni adaylarının bazı değişkenler açısından fen öğretimi öz-yeterlik inanç düzeylerinin ve sonuç beklentilerinin incelenmesi üzerine bir araştırma. Türk Fen Eğitimi Dergisi, 8(3), 69-79.

Karamustafaoğlu, O., Uluçınar Sağır, Ş. ve Özkan, M. (2012).“Öğretmen Adaylarının Fen Öğretimine Yönelik Öz-Yeterlik İnançları", X. Ulusal Fen Bilimleri ve Matematik Eğitimi Kongresi Bildiri Özetleri Kitabı, Niğde.

Karasar, N. (2006). Bilimsel araştırma yöntemi (9. bask.). Ankara: Nobel Yayınları.

Kayhan Yardımcı, F.(2007). "ilköğretim Öğrencilerinde Algılanan Sosyal Destek Ile Öz-Yeterlik ilişkisi ve Etkileyen Değişkenlerin incelenmesi". Yayınlanmamış Doktora Tezi, Ege Üniversitesi, Sağlık Bilimleri Enstitüsü.

Kemp, S. D. (2011)"Academic self-efficacy and middle school students: A study of advisory class teaching strategies and academic self-efficacy", Yayınlanmamış Doktora Tezi, La Sierra University, California.

Klem, L. (2000). Structural equation modeling. in: L.G. Grimm, P.R. Yarnold (Eds.), Reading and Understanding More Multivariate Statistics. American Psychological Association, Washington, DC, pp. 227-260.

Köseoğlu, P. (2010). Biyoloji eğitiminde birleştirme tekniği temelli öğretimin akademik başarı, özyeterlik ve tutuma etkisi. Hacettepe Üniversitesi Eğitim Fakültesi Dergisi, 39, 144-254.

Lee, E. E. (2003). "Cultural Mistrust, University Alienation, Academic Self-Efficacy and Academic Help Seeking in African American College Students". Yayınlanmamış Doktora Tezi, University of Nebraska, Lincoln.

MEB, (2013). http://www.meb.gov.tr/2014-2015-egitim-ogretim-yili-elektronik-ortamda-hizmetesunulan-ilk-ve-orta-ogretim-ders-kitaplari/duyuru/7013 (Erişim Tarihi: Mart 2015).

Morgil, I.., Yılmaz, A. ve Cingör, N. (2002).“Fen eğitiminde çevre ve çevre koruma projesi hazırlamasına yönelik çalışma", V. Ulusal Fen bilimleri ve Matematik Eğitimi Kongresi Bildiriler Kitabı. 45, Ankara.

O'Leary, M. (2005). "A Comparison of Female and Male Teacher's Self-efficacy in Science and a Comparison of Science Motivation Beliefs in Students with High Science Self-efficacy vs. Low Science Self-efficacy Teachers", Doktora Tezi, Kean University, New Jersey.

Özdamar, K. (2013). Paket programlar ile istatistiksel veri analizi. Eskişehir: Kaan Kitabevi, 
Özdemir, S. M. (2008). Sınıf öğretmeni adaylarının öğretim sürecine ilişkin öz-yeterlik inançlarının çeşitli değişkenler açısından incelenmesi. Kuram ve Uygulamada Eğitim Yönetimi Dergisi, 14(2), 277-306.

Özenoğlu Kiremit, H. ve Gökler, ì. (2010). Fen bilgisi öğretmenliği öğrencilerinin biyoloji öğretimi ile ilgili öz-yeterlik inançlarının karşılaştırıması.Pamukkale Üniversitesi Eğitim Fakültesi Dergisi, 27(27), 41-54.

Özenoğlu Kiremit, H. (2006). "Fen Bilgisi Öğretmenliği Öğrencilerinin Biyoloji ile İlgili Öz-Yeterlik İnançlarının Karşılaştırılması". Yayınlanmamış Doktora Tezi, Dokuz Eylül Üniversitesi, Eğitim Bilimleri Enstitüsü.

Sağır, S. U. ve Bertiz, H. (2016). Fen bilimleri öğretmenliği öğrencileri ve pedagojik formasyon fen grubu öğrencilerinin yansıtıcı düşünme becerilerinin karşılaştırılması. Bartin Üniversitesi Egitim Fakültesi Dergisi, 5(2), 385.

Satıcı, S. A. (2013). “Üniversite Öğrencilerinin Akademik Öz-Yeterliklerinin Çeşitli Değişkenler Açııından incelenmesi". Yüksek Lisans Tezi, Anadolu Üniversitesi, Eğitim Bilimleri Enstitüsü, Eskişehir.

Schunk, D. H. ve Pajares, F. (2001). The development of academic self-efficacy, in: A. Wigfield, J. Eccles (Eds.), Development of Achievement Motivation. San Diego: Academic Press, Inc. pp. 1531.

Sezgin Saf, A. (2011). “Ortaöğretim 9. Sını Öğrencilerinin Kimya Dersine Ilişkin Tutum, Motivasyon ve Öz Yeterlik Algılarının Çeşitli Değişkenler ile incelenmesi". Yayınlanmamış Yüksek Lisans Tezi, Selçuk Üniversitesi, Eğitim Bilimleri Enstitüsü.

Shultz, D. P. ve Shultz, S.E. (2007). Modern psikoloji tarihi. (Çev: Aslay, Y.). İstanbul: Kaknüs Yayınları.

Smist, M. J. (1993). "General Chemistry and Self Efficacy", Paper presented at the National Meeting of the American Chemical Society, Ağustos.

Tabachnick, B. G. ve Fidell, L. S.(2001). Using multivariate statistics. New York. MA: Allyn \& Bacon,

Tavşancıl, E. (2014). Tutumların ölçülmesi ve spss ile veri analizi (5. Baskı). Nobel Akademik Yayıncılık, Ankara.

Tschannen-Moran, M., Hoy, A. W. ve Hoy, W. K. (1998). Teacher efficacy: Its meaning and measure. Review of Educational Research, 68, 202-248.

Wuebbels, A. L. (2006). "The Development of a Social Emotional and Academic Self-Efficacy Curriculum for Sixth Grade Adolescent Students". Yayınlanmamış Doktora Tezi, School of Saint Louis University, Missouri.

Yıldız, V. G., Yıldırım, A. ve İlhan, N. (2006). Üniversite kimya öğrencilerinin asitler ve bazlar hakkındaki bilgilerini günlük hayatla ilişkilendirebilme düzeyleri. VII. Ulusal Fen Bilimleri ve Matematik Eğitimi Kongresi, Gazi Üniversitesi, Eylül 7-9, Ankara. 


\section{Extended Summary}

It is important to determine the perception of self-efficacy level about science issues of science teachers. In the literature, there is not research about on self-efficacy are associated with certain chemistry topics. Perception of self-efficacy in "Social Learning Theory" of Bandura is defined as personal judgements of individuals respecting that whether they can do the necesssary things to overcome the situations they face (Bandura, 1977). It is known that the perceived self-efficacy is not an individual's ability to do a task but it's his personal judgment and beliefs concerned with completing that task successfully or not (Bandura, 1977; Bong, 1995). Perceived self-efficacy may change up to individuals, societies and areas and may affect the communication of individuals with their environment (Bandura, 1997). Studies regarding the perception of self-efficacy on educational field generally focused on teachers and pre-service teachers (O' leary, 2005; Deniş \& Genç, 2010). Self-efficacy perception of teachers expresses their personal judgements that they can effect the learning process (Tschannen- Moran \& Woolfolk-Hoy, 1998). As teachers having high self-efficacy in their profession ensure them to be successful and attentive in their profession and enthusiastic and patient in their classes, the performance of the students are affected positively by this situation (Aydın, 2008). It is known that self-efficacy perception of teachers has positive effects on application of activities in process of teaching and learning, and on developments of students (Tschannen-Moran, Woolfolk-Hoy \& Hoy, 1998). Teachers' self-efficacy perceptions may vary according to their fields (Bandura, 1986).

Teachers can spare more time to some subjects due to their perceptions of self-efficacy, and they can prefer participating in the activities on which they feel themselves sufficient. In this sense, it is significant to determine the self-efficacy perceptions of pre-service teachers of sciences oriented at acid-base topic which is one of the key subjects of chemistry lesson at high-school and university, and to determine the variables which are supposed to effect this perception.

The aim of this study is to develop "Acid-Base Self-Efficacy Perception Scale (ABSPS)" and to investigate the level of pre-service science teachers' self-efficacy perceptions on acid-base topic in terms of various variables (gender, grade, the type of high schools graduated and achievement at General Chemistry II lesson). The present study was conducted in two stages. In the first stage, it has been demonstrated reliability and validity of the ABSPS. In the study, ABSPS was used as the data collection tool. ABSPS, a five-point likert type, consists of two dimensions ("Relating to daily life", "Knowledge on topic and scientific explanation") and 14 items. The sample of reliability and validity of the ABSPS consists 453 pre-service science teachers in department of science education at three different state universities.

The following transactions have been made to ensure the scale's content and face validity: a) the create of a theoretical framework, b) the create of the item pool c) Receipt of expert opinions, d) make of pilot application. The following transactions have been made to ensure the scale's construct validity: a) item analysis based on correlation b) item analysis based on mean difference of sub-top group, c) exploratory factor analysis, d) correlational relationship between factors, e) after factor analysis, the item-total correlation. The transaction has been made to ensure the scale's reliability analysis: The calculation of Cronbach's Alpha. In the second part of the study, it has been investigated the level of pre-service science teachers' self-efficacy perceptions on acidbase topic in terms of various variables (gender, grade, the type of high schools graduated and achievement at General Chemistry II lesson). Survey method was used. The sample of the study consists of 982 pre-service science teachers in department of science education at eight different state universities. Data was collected by researchers or by academic staff at universities. Before application, information was given about how to fill the scale for pre-service science teachers. It had been reported orally that no needed their personal identifying information because of there will be no individual evaluations of pre-service science teachers. The participation of the study that voluntary basis of pre-service science teachers announced them by researchers. It had been 
announced that can receive information about research results and findings after the research was completed. Time was not taken to restrict the application of the scale.

For the collected data in the study, the reliability coefficient Cronbach's Alpha was 0.823 . The dimensions of ABSPS were determined by confirmatory factor analysis. Data were analyzed by using descriptive statistics, independent samples t-test and one-way analysis of variance (ANOVA).

According to the findings, mean of the items at ABSPS ranged from 3.281 to 4.142. Item 7: While using acidic or basic materials (bleach, drain opener and etc.), I can take precautions in terms of health and safety $(M=4.142)$. Item 11: I feel myself efficient in scientific discussions about acids and bases. $(M=3.281)$. When analyzed in terms of gender, levels of self-efficacy perceptions on acidbase topic of the female pre-service science teachers $(M=53.50)$ were significantly higher than the male pre-service science teachers $(M=51.16), t(980)=4.36, p<0.05)$. When analyzed in terms of grade, it was found that $2^{\text {nd }}$ and $3^{\text {th }}$ grade pre-service science teachers' self-efficacy perceptions on acid-base topic was significantly higher than $1^{\text {st }}$ grade pre-service science teachers' self-efficacy perceptions on acid-base topic, $F(3,978)=6.788, p<0,05$. Results indicated that there were no significant differences in pre-service science teachers' self-efficacy perceptions on acid-base topic in terms of graduated high school type, $F(2,979)=0.426, p>0,05$. And finally in terms of achievement of "General Chemistry II" course, results indicated that level of pre-service science teachers' selfefficacy perceptions on acid-base topic who have high scores in "General Chemistry II" course, were significantly higher than the pre-service science teachers who have lower scores in this course, $F(3,670)=4.064, \mathrm{p}<0.05$.

The results show that pre-service science teachers' self-efficacy perceptions on acid-base topic vary in terms of gender, grade and "General Chemistry II" course scores. Studies which are examining self-efficacy related to Chemistry topics would contribute to the literature in order to develop preservice science teachers' self-efficacy perception related to chemistry topics. 